\title{
In Vitro Inhibition of Linoleic Acid Peroxidation by Primary S-Nitrosothiols
}

\author{
Fernanda I. Simplicio, Amedea B. Seabra, Gabriela F. P. de Souza and \\ Marcelo G. de Oliveira* \\ Instituto de Química, Universidade Estadual de Campinas, CP 6154, \\ 13083-970 Campinas-SP, Brazil
}

\begin{abstract}
O óxido nítrico ( $\mathrm{NO}$ ) é um antioxidante efetivo na inibição da peroxidação lipídica e circula in vivo principalmente como S-nitrosotióis primários (RSNOs). Neste trabalho, a peroxidação in vitro de comicelas do ácido linileico-SDS (LA-SDS) catalisada por lipoxigenase de soja (SLO) e íons $\mathrm{Fe}^{\mathrm{II}}$ foi monitorada na presença e na ausência de três RSNOs: S-nitrosocisteína, S-nitroso-Nacetilcisteína e S-nitrosoglutationa. Medidas cinéticas baseadas na formação de duplas ligações conjugadas e adutos fluorescentes de lisina-La oxidado mostraram que os RSNOs são antioxidantes mais potentes que seus tióis livres (RSHs) correspondentes em condições equimolares. Esses resultados são consistentes com o bloqueio da peroxidação de LA-SDS por RSNOs através da inativação dos radicais peroxila/alcoxila (LOO*/LO*), levando a produtos nitrogenados do LA oxidado, os quais liberam 'NO. Esses resultados indicam que os RSNOs endógenos podem desempenhar um papel importante no bloqueio da peroxidação lipídica in vivo, através da inativação primária de radicais alcoxila/peroxila bem como de hidroperóxidos lipídicos pré-formados.
\end{abstract}

Nitric oxide $\left({ }^{\circ} \mathrm{NO}\right)$ is an effective chain-breaking antioxidant in the inhibition of lipid peroxidation and circulates in vivo mainly as primary S-nitrosothiols (RSNOs). In this work, the in vitro peroxidation of linoleic acid-SDS comicelles (LA-SDS) catalyzed by soybean lipoxygenase (SLO) and $\mathrm{Fe}^{\mathrm{II}}$ ions was monitored in the presence and absence of three primary RSNOs: S-nitrosocysteine, S-nitroso-N-acetylcysteyne and S-nitrosoglutathione. Kinetic measurements based on the formation of conjugated double bonds and fluorescent oxidized LA-lysine adducts, showed that RSNOs are more potent antioxidants than their corresponding free thiols (RSHs) in equimolar conditions. These results are consistent with the blocking of LA-SDS peroxidation by RSNOs through the inactivation of peroxyl/alkoxyl (LOO/LO') radicals, leading to nitrogencontaining products of oxidized LA, which release free ${ }^{\circ} \mathrm{NO}$. These results indicate that endogenous RSNOs may play a major role in the blocking of lipid peroxidation in vivo, through the primary inactivation of alkoxyl/peroxyl radicals and also of preformed lipid hydroperoxides.

Keywords: nitric oxide, S-nitrosothiols, lipid peroxidation, linoleic acid, lipoxygenase

\section{Introduction}

An increasing amount of evidence has demonstrated that oxidative and nitrosative stresses, play a fundamental role in atherosclerosis and in other diseases associated with lipid peroxidation (LPO). ${ }^{1-6}$ In these cases, it is assumed that free radicals which normally play an essential role in metabolic processes, are released from the active site of enzymes, triggering a cascade of deleterious effects on cells. $^{7}$ These effects involve the interaction of free radicals with metal or organic redox centers and the promotion of irreversible oxidation reactions beyond the normal catalytic

*e-mail: mgo@iqm.unicamp.br cycles. Once formed, free radicals are also capable of initiating other radical reactions, which may become selfsustaining through the regeneration of propagating radicals which are involved in the oxidation of lipids in humans representing a key event in the atherosclerotic process. This conclusion is reinforced by the fact that both primary and secondary lipid oxidation products are found in human atherosclerotic lesions. ${ }^{8,9}$

Under normal physiological conditions, endotheliumderived nitric oxide (nitrogen monoxide, ${ }^{\circ} \mathrm{NO}$ ) has multiple physiological functions in humans, like the regulation of vascular tone in both the systemic and renal circulation, ${ }^{10,11}$ the prevention of adherence and aggregation of platelets and monocytes in the walls of blood vessels ${ }^{12}$ and the regulation 
of the proliferation and migration of smooth muscle cells. ${ }^{13}$ In addition to the actions related to the mediation of signal transduction, via stimulation of guanylate cyclase-mediated cGMP synthesis, NO has been shown to exert several antiatherogenic properties assigned to its ability to react directly with free radicals, blocking the propagation of radical reactions. This protective effect has already been observed in model lipid systems, ${ }^{14,15}$ low-density lipoproteins $(\mathrm{LDL})^{16-18}$ and cells ${ }^{19,20}$ and is supported by several in vitro studies which have demonstrated the formation of nitrogencontaining products of polyunsaturated fatty acids (PUFA), including alkylnitrites (RONO), alkylnitrates (ROONO and $\left.\mathrm{RONO}_{2}\right)$, alkylepoxynitrite $\left(\mathrm{R}(\mathrm{O}) \mathrm{NO}_{2}\right)$, alkylnitrohydroxy $\left(\mathrm{RNO}_{2} \mathrm{OH}\right)$, and nitrolipids $\left(\mathrm{RNO}_{2}\right)$, when PUFAs are oxidized in the presence of ${ }^{\circ} \mathrm{NO}$. Such products have already been characterized in other works by mass spectrometry and can be taken as markers of the in vivo pro-oxidant and/or antioxidant actions of ${ }^{N} \mathrm{NO} \cdot{ }^{14,15,21-28}$ These results stimulate new therapeutic approaches for treating lipid peroxidationrelated diseases by enhancing ${ }^{\mathrm{NO}}$ synthesis and/or activity by administration of L-arginine and antioxidants. ${ }^{29} \mathrm{As}$ an alternative strategy, compounds that act as $\mathrm{NO}$ donors could be administrated as exogenous NO sources, as already demonstrated for the treatment of hepatic steatosis via oral administration of the S-nitrosothiol (RSNO) S-nitroso-Nacetylcysteine (SNAC). ${ }^{3-6}$ RSNOs are peptides or proteins carrying the S-NO moiety and were shown to occur in the plasma and cells of mammals where they have the same physiological functions of free ${ }^{\mathrm{NO}} \mathrm{like}$ vasodilation, ${ }^{30,31}$ inhibition of platelet activation and aggregation ${ }^{32,33}$ and post-translational modification of protein function. . $^{34,35}$ S-nitrosoglutathione (GSNO), S-nitrosoalbumin and S-nitrosohemoglobin, for example, have been considered to be ${ }^{\mathrm{NO}}$ carriers and donors in humans and are the focus of several studies both in vivo and in vitro. ${ }^{36}$ Other RSNOs, like S-nitrosocysteine (CySNO) have also been described. ${ }^{37}$ What classifies a RSNO as primary is the fact that the sulfur atom of its SNO moiety is bound to a primary carbon atom (Figure 1), while in S-nitroso-N-acetylpenicillamine (SNAP), which is widely used in experimental studies, the sulfur atom is bound to a tertiary carbon atom, making it a "tertiary" RSNO. Evaluating the antioxidant properties of primary RSNOs may have an additional relevance, once the lability of ${ }^{\mathrm{NO}}$ in primary and tertiary RSNOs can be different. ${ }^{37-39}$ In any case, one of the important characteristics of having ${ }^{\circ} \mathrm{NO}$ carried as RSNOs is its preservation from inactivation caused by reaction with oxygen, leading to nitrite $\left(\mathrm{NO}_{2}^{-}\right)$and further to nitrate $\left(\mathrm{NO}_{3}^{-}\right){ }^{40}$ two of the main end products of $\mathrm{NO}$ metabolism. Although several exogenous "NO sources (which are not found endogenously) have been used as antioxidants in LPO studies like organic nitrites and NONOates, ${ }^{41}$ only one work has reported the protective role of primary RSNOs in blocking LPO reactions. ${ }^{42}$

In this work, the in vitro peroxidation of linoleic acid SDS comicelles (LA-SDS) catalyzed by soybean lipoxygenase (SLO) and by $\mathrm{Fe}^{\mathrm{II}}$ ions was monitored in the presence and absence of three primary RSNOs: CySNO, SNAC and GSNO and of their corresponding free thiols (RSHs), at $37^{\circ} \mathrm{C}$. Kinetic data showed that RSNOs can block LA peroxidation much more efficiently than RSHs, by inactivating alkoxyl/peroxyl $\left(\mathrm{LO}^{\circ} / \mathrm{LOO}^{*}\right)$ radicals and LA hydroperoxides, $(\mathrm{LOOH}=$ 13-hydroperoxy-octadecadienoic acid, 13-HPODE) through nitration and transnitrosation reactions. These results suggest that endogenous primary RSNOs may play a major role in blocking lipid peroxidation in vivo.

\section{Experimental}

\section{Reagents}

Ascorbic acid, cysteine ( $\mathrm{CySH})$, ferrous sulfate $\left(\mathrm{FeSO}_{4}\right)$, copper sulfate $\left(\mathrm{CuSO}_{4}\right)$, glutathione (g-Glu-CysGlu, GSH), linoleic acid (LA), L-lysine monohydrochloride (Lys), malonaldehyde bis(dimethyl acetal) (MDA), $\mathrm{N}$-acetyl-L-cysteine (NAC), phosphate buffer saline (PBS, $\mathrm{pH}$ 7.4), sodium dodecil sulfate (SDS), sodium nitrite $\left(\mathrm{NaNO}_{2}\right)$, soybean lipoxygenase (SLO), hydrochoric acid ( $\mathrm{HCl})$, mercury chloride $\left(\mathrm{HgCl}_{2}\right)$, tert-butyl hydroperoxide $\left({ }^{t} \mathrm{BOOH}, \mathrm{C}_{4} \mathrm{H}_{10} \mathrm{O}_{2}\right.$ ) (Sigma/Aldrich, St. Louis, MO) and sulfanilamide (Merck, Germay), were used as received. All the experiments were carried out using analytical grade water from a Millipore Milli-Q gradient filtration system.

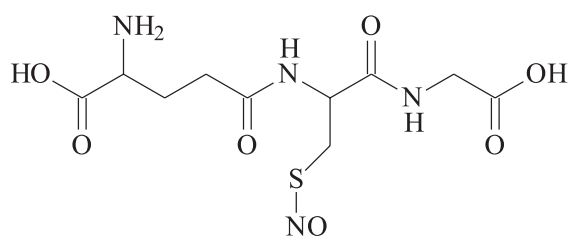

GSNO<smiles>NC(CSN=O)C(=O)O</smiles>

CySNO<smiles>CC(=O)NC(CSN=O)C(=O)O</smiles>

SNAC

Figure 1. Molecular structures of S-nitroso-L-cysteine (CySNO), S-nitroso-N-acetylcysteine (SNAC) and S-nitrosoglutathione (GSNO). 


\section{Synthesis of GSNO, CySNO and SNAC in aqueous solution}

Aqueous GSNO solution was prepared by the reaction of GSH with sodium nitrite in acidic medium as described elsewhere. ${ }^{37,43}$ GSNO was obtained as stable reddish crystals in the pure form and was dried by freeze-drying. Freshly prepared GSNO solutions in PBS were used in the experiments. S-nitroso-N-acetylcysteine (SNAC) and S-nitrosocysteine (CySNO) cannot be precipitated from solution and stored as dry solids because of their high solubility in water. Therefore, aqueous SNAC or CySNO solutions were synthesized through the equimolar reaction of $\mathrm{NAC}$ or CyS, respectively, with $\mathrm{NaNO}_{2}$ in acidified aqueous solution. Stock acidic SNAC and CySNO solutions freshly prepared, were diluted in PBS and used immediately.

\section{Characterization of linoleic acid peroxidation}

Linoleic acid (LA) peroxidation was induced through the addition of SLO to aqueous LA dispersions (final concentration $\left.19 \mathrm{mmol} \mathrm{L}^{-1}\right)$ in SDS solution $\left(0.01 \mathrm{~mol} \mathrm{~L}^{-1}\right)$ (LA-SDS comicelles). Each LA dispersion was transferred to a quartz cuvette, blowed with $\mathrm{O}_{2}$ for 2 min and SLO (final concentration $56 \mathrm{nmol} \mathrm{L}^{-1}$ ) was added to the cuvette with a syringe to start the peroxidation reaction. Peroxidation reactions were monitored in the absence or presence of $\mathrm{CySH}$, NAC and GSH (final concentrations $560 \mathrm{mmol} \mathrm{L}^{-1}$ ) and of their corresponding RSNOs, CySNO, SNAC and GSNO, respectively (final concentrations $56 \mathrm{mmol} \mathrm{L}^{-1}$ ), through the increase in absorbance at $234 \mathrm{~nm}$, due to conjugated diene formation. A Hewlett Packard spectrophotometer, model 8453 (Palo Alto, CA, USA) with a temperature-controlled cuvette holder was used to monitor the spectral changes in the range $200-600 \mathrm{~nm}$ in the dark at $37^{\circ} \mathrm{C}$, in time intervals of $2 \mathrm{~s}$. Spectra of the solutions were obtained in $1 \mathrm{~cm}$ quartz cuvette, under stirring $\left(1,000 \mathrm{r} \mathrm{min}^{-1}\right)$. Each point in the kinetic curves of absorbance $v s$. time is the average of two experiments with error bars expressed by their standard errors of the mean (SEM). Statistical differences among the initial rates $\left(\mathrm{I}_{\mathrm{r}}\right)$ of LA peroxidation, catalyzed by SLO, in the absence and presence of RSHs and their corresponding RSNOs were evaluated using ANOVA followed by TukeyKramer multiple test.

\section{Characterization of fluorescent MDA-lysine adduct}

To characterize the emission spectrum of the fluorescent adduct formed in the reaction of oxidized linoleic acid (oxLA) and lysine, an MDA-lysine adduct was prepared as a model adduct by reacting MDA with L-lysine in equimolar condition (final concentration $0.25 \mathrm{~mol} \mathrm{~L}^{-1}$ ) in PBS solution at room temperature and the emission spectrum was obtained in the range 375-600 nm, with excitation wavelength of $360 \mathrm{~nm}$.

Spectrofluorimetric characterization and monitoring of oxidized LA-lysine adduct formation

LA peroxidation was induced through the addition of aqueous $\mathrm{FeSO}_{4}$ solution (final concentration $5.0 \mu \mathrm{mol} \mathrm{L}^{-1}$ ) to aqueous LA (final concentration $1.2 \mathrm{mmol} \mathrm{L}^{-1}$ ) dispersions in SDS solution (final concentration $0.01 \mathrm{~mol} \mathrm{~L}^{-1}$ ) in the absence or presence of GSNO (final concentrations 5 and $500 \mathrm{mmol} \mathrm{L}^{-1}$ ) for $2 \mathrm{~h}$ in PBS ( $\mathrm{pH}$ 7.4). After LA oxidation, lysine solution (final concentration $1.0 \mathrm{mmol} \mathrm{L}^{-1}$ ) was transferred to the dispersions followed by incubation for $48 \mathrm{~h}$. The kinetics of formation of fluorescent oxidized LA-lysine adduct (oxLA-Lys) in the reaction between oxLA and Lys during the incubation time was characterized based on the spectral changes in the range 375 to $600 \mathrm{~nm}$ and on the emission intensity at $430 \mathrm{~nm}$, under excitation at $360 \mathrm{~nm}$. All the spectrofluorimetric measurements were performed using a Perkin-Elmer LS55 spectrofluorimeter with a temperature-controlled cuvette holder at $37^{\circ} \mathrm{C}$.

\section{Infrared characterization of linoleic acid peroxidation}

Linoleic acid peroxidation was induced by heating a sample of pure LA at $80^{\circ} \mathrm{C}$ for $4 \mathrm{~h}$ under stirring in a glass flask with $\mathrm{O}_{2}$ atmosphere, obtained by continuously blowing $\mathrm{O}_{2}$ from a cylinder into the headspace of the flask. Aliquots of LA were removed from the reaction flask 2 and $4 \mathrm{~h}$ after the beginning of the peroxidation reaction. Capillary films of non-oxidized and peroxidized LA were obtained between two calcium fluoride $\left(\mathrm{CaF}_{2}\right)$ windows, which were mounted in special sample holder. IR spectra were obtained in the range $4000-1000 \mathrm{~cm}^{-1}$ using an FTIR Bomem MB-series, model B-100. An IR spectrum of nonoxidized LA was obtained as a control.

Detection of ${ }^{\circ} \mathrm{NO}$ released from nitrogen-containing products of oxidized LA

Nitric oxide released from nitrogen-containing products of oxLA formed in the peroxidation of LA in the presence of GSNO, was detected using a gasphase chemiluminescence-based nitric oxide analyzer (NOA, Sievers, Bolder Co, USA). Peroxidation of LA was induced by two different procedures. In the first, the LA-SDS dispersion in the presence of $\mathrm{Cu}^{\mathrm{II}}$ (900 $\mathrm{mmol} \mathrm{L}^{-1}$ ) ions was previously blowed with $\mathrm{O}_{2}$ for $2 \mathrm{~min}$, followed by incubation with GSNO $\left(900 \mathrm{mmol} \mathrm{L}^{-1}\right)$ 
for $30 \mathrm{~min}$ at room temperature. In the second, peroxidation of LA was induced by heating a sample of pure LA at $80^{\circ} \mathrm{C}$ for $1 \mathrm{~h}$ under stirring in a glass flask with $\mathrm{O}_{2}$ atmosphere, obtained by continuously blowing $\mathrm{O}_{2}$ from a cylinder into the headspace of the flask. After oxidation, oxLA was dispersed in SDS solution $\left(0.01 \mathrm{~mol} \mathrm{~L}^{-1}\right)$ and incubated with GSNO, for $30 \mathrm{~min}$ at room temperature. In both cases, after incubation, non-reacted excess GSNO was removed from the solution by adding $\mathrm{HgCl}_{2}$ (final concentration $29.4 \mathrm{mmol} \mathrm{L}^{-1}$ ) and allowing GSNO decomposition to GS-SG and free $\mathrm{NO}$ to proceed for $15 \mathrm{~min}$. In this condition, $\mathrm{NO}$ is quantitatively released from excess GSNO by mercuric catalysis and is rapidly and quantitatively converted to its stable end product, nitrite $\left(\mathrm{NO}_{2}^{-}\right)$. Nitrite formed was removed by adding a $10 \% \mathrm{v} / \mathrm{v}$ solution of sulfanilamide $\left(6.0 \mathrm{mmol} \mathrm{L}^{-1}\right.$ in $\mathrm{HCl}$ $2 \mathrm{~mol} \mathrm{~L}^{-1}$ ), followed by incubation for $15 \mathrm{~min}$. A volume of $5 \mathrm{~mL}$ of aqueous saturated ascorbic acid solution, used as a reducing agent, was added in the glass purge vessel of the NOA. Antifoaming agent was used to prevent foaming caused by injection of the samples. Volumes of $100 \mathrm{~mL}$ of the final nitrogen-containing products of oxLA suspension were injected in the glass purge vessel containing ascorbic acid, through an impermeable septum. Nitrogen gas (Air Liquid, Brazil) was bubbled through the solution and free $\mathrm{NO}$ formed due to the reduction of nitrogen-containing products of oxLA by ascorbic acid in the glass purge vessel was carried into the reaction chamber for detection. Control curves are for the measurements of samples of water incubated with GSNO $900 \mathrm{mmol} \mathrm{L}^{-1}$ without LA-SDS and $\mathrm{Cu}^{\mathrm{II}}$ for $30 \mathrm{~min}$ at room temperature (control 1), and of water incubated with GSNO $900 \mathrm{mmol} \mathrm{L}^{-1}$ and $\mathrm{Cu}^{\mathrm{II}}$ without LA-SDS for $30 \mathrm{~min}$ at room temperature (control 2). In both cases, the incubations were followed by the addition of $\mathrm{HgCl}_{2}$ (final concentration $29.4 \mathrm{mmol} \mathrm{L}^{-1}$ ) for promoting GSNO decomposition to GS-SG and free $\mathrm{NO}$ for 15 min and by the addition of a $10 \% \mathrm{v} / \mathrm{v}$ solution of sulfanilamide $\left(6.0 \mathrm{mmol} \mathrm{L}^{-1}\right.$ in $\left.\mathrm{HCl} 2 \mathrm{~mol} \mathrm{~L}^{-1}\right)$, for 15 min for eliminating nitritre formed in the reaction between $\mathrm{NO}$ and $\mathrm{O}_{2}$.

\section{Reaction between RSNOs and tert-butyl hydroperoxide}

The formation of tert-butyl peroxynitrites ('BOONOs) in the reactions between tert-butyl hydroperoxide $\left({ }^{t} \mathrm{BOOH}\right)$ and RSNOs was characterized by following the decomposition of GSNO, SNAC and CySNO (initial concentrations $1 \mathrm{mmol} \mathrm{L}^{-1}$ ) upon the addiction of ${ }^{t} \mathrm{BOOH}$ (initial concentration $25 \mathrm{mmol} \mathrm{L}^{-1}$ ) in basic medium (pH 12). The decomposition of RSNOs in absence or presence of $\mathrm{tBOOH}$ was characterized by following the spectral changes of RSNOs solutions in the range 220-1100 nm in the dark, in a $1 \mathrm{~cm}$ quartz cuvette referenced against air. Kinetic curves of GSNO, SNAC and CySNO decomposition were obtained from the absorption changes at $336 \mathrm{~nm}$ in time intervals of $15 \mathrm{~s}$, at $37^{\circ} \mathrm{C}$, for $8 \mathrm{~min}$. The control experiment was performed by incubating RSNOs with pure water at $\mathrm{pH} 12$, adjusted with $\mathrm{NaOH}$ solution. Each point in the kinetic curves of concentration vs. time is the average of two experiments with error bars expressed by their standard errors of the mean (SEM).

\section{Results and Discussion}

\section{Kinetic characterization of linoleic acid peroxidation}

Figure 2 shows the kinetic curves corresponding to the spectral changes monitored at $234 \mathrm{~nm}$ in the first $80 \mathrm{~s}$ of LA oxidation by SLO in the presence of RSHs and RSNOs. The band at $234 \mathrm{~nm}$ is associated with the formation of conjugated double bonds in LA, as a result of LA peroxidation. ${ }^{35}$ In this time range, the curves reach an apparent plateau after $c a .20 \mathrm{~s}$ in all cases. The initial rates of reaction $\left(\mathrm{I}_{\mathrm{r}}\right)$, as well as the height of the plateaus, are decrease significantly in the presence of RSHs and RSNOs, compared to the peroxidation of LA alone. As the height of the plateaus can be taken as a measurement of the extent of the peroxidation reaction in its initial phase, this result indicates that RSNOs in concentrations ten times lower than their corresponding RSHs ( 56 versus $560 \mathrm{mmol} \mathrm{L}^{-1}$ ) exert a much more extensive blockage of the peroxidation reaction than the corresponding RSHs in this time range.

The initial rates of LA peroxidation $\left(\mathrm{I}_{\mathrm{r}}\right)$, extracted from the curves of Figure 2 are shown in the bar graphs of Figure 3 for comparison. It can be seen that the $I_{r}$ of LA $\left(19 \mathrm{mmol} \mathrm{L}^{-1}\right)$ peroxidation is decreased to about $1 / 2$ of the control value in the presence of RSHs $\left(560 \mathrm{mmol} \mathrm{L}^{-1}\right)$, i.e., at a molar ratio $\mathrm{RSH} / \mathrm{LA}=29.5$, with no significant differences among the antioxidant actions of $\mathrm{CySH}$, NAC and GSH. In contrast, the presence of RSNOs at a concentration ten times lower $\left(56 \mathrm{mmol} \mathrm{L}^{-1}\right)$, i.e., at a molar ratio $\mathrm{RSH} / \mathrm{LA}=2.9$ reduced $\mathrm{I}_{\mathrm{r}}$ values to $c a .1 / 5$ of the control value, also with no significant differences among the action of CysNO, SNAC and GSNO.

\section{Fluorimetric characterization and monitoring of oxidized LA-lysine adduct formation}

Figure 4 shows the emission spectra obtained after LA oxidation catalyzed by $\mathrm{Fe}^{\mathrm{II}}$ ions for $2 \mathrm{~h}$, followed by incubation of the solution with lysine for $48 \mathrm{~h}$ at 


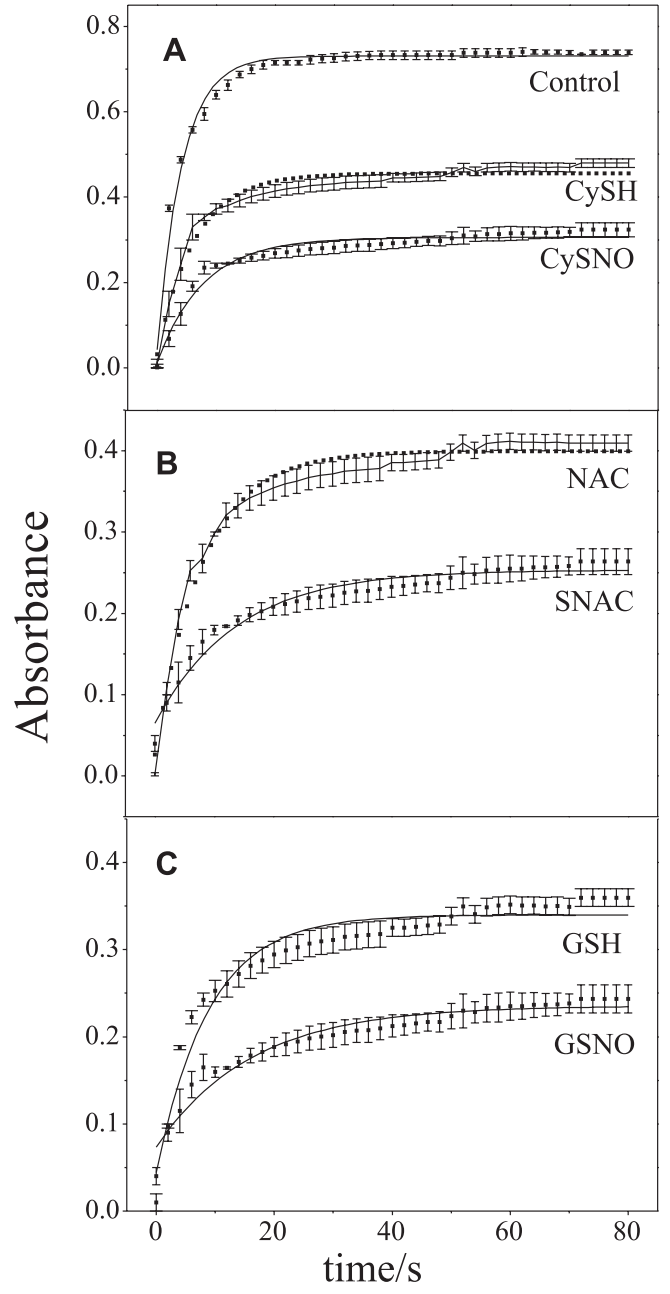

Figure 2. Kinetic curves of LA ( $\left.19 \mathrm{mmol} \mathrm{L}^{-1}\right)$ peroxidation catalyzed by (SLO) $\left(56 \mathrm{nmol} \mathrm{L}^{-1}\right)$, in the absence of RSH or RSNO (Control, A) and in the presence of CySH $560 \mathrm{mmol} \mathrm{L}^{-1}$ and CySNO $56 \mathrm{mmol} \mathrm{L}^{-1}$ (A); NAC $560 \mathrm{mmol} \mathrm{L}^{-1}$ and SNAC $56 \mathrm{mmol} \mathrm{L}^{-1}$ (B) and GSH $560 \mathrm{mmol} \mathrm{L}^{-1}$ and GSNO $56 \mathrm{mmol} \mathrm{L}^{-1}(\mathrm{C})$. Absorbance changes were monitored at $234 \mathrm{~nm}$ at $37^{\circ} \mathrm{C}$.

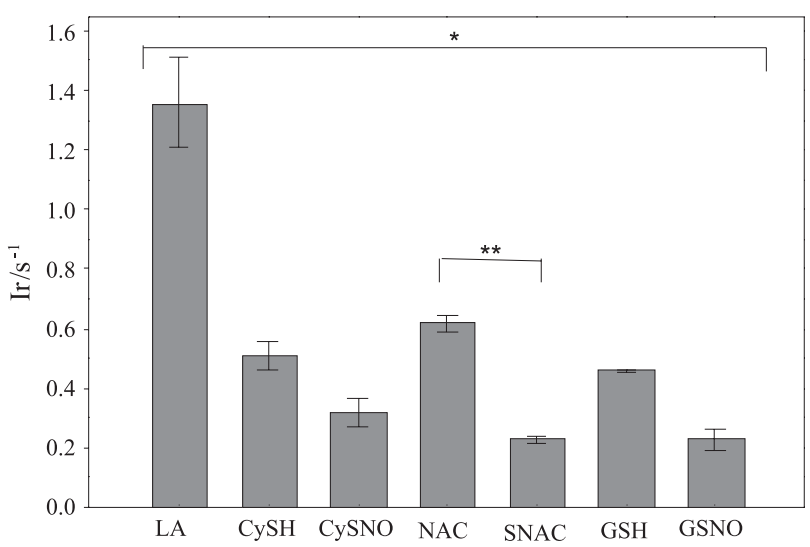

Figure 3. Initial rates $\left(\mathrm{I}_{\mathrm{r}}\right)$ achieved after $c a .20 \mathrm{~s}$ of LA peroxidation, catalyzed by SLO, in the absence and presence of RSHs and their corresponding RSNOs at concentrations ten times lower. $[\mathrm{LA}]=19 \mathrm{mmol} \mathrm{L}^{-1} ;[\mathrm{SLO}]=56 \mathrm{nmol} \mathrm{L}{ }^{-1} ;[\mathrm{RSHs}]=560 \mathrm{mmol} \mathrm{L}^{-1}$ and $[\mathrm{RSNOs}]=56 \mathrm{mmol} \mathrm{L}^{-1}$. Data extracted from the kinetic curves of Figure 2. $* \mathrm{p}<0.001 ; * \mathrm{p}<0.05$.
$37{ }^{\circ} \mathrm{C}$. The peroxidation reactions were performed in the absence (a) and presence of GSNO $5.0 \mathrm{mmol} \mathrm{L}^{-1}$ (b) and $500.0 \mathrm{mmol} \mathrm{L}^{-1}$ (c). The inset in Figure 4 shows the emission spectrum obtained after the incubation of MDA with lysine in equimolar concentrations of $0.25 \mathrm{~mol} \mathrm{~L}^{-1}$, as a control experiment. Figure 5 shows the kinetic curves of the fluorescent oxLA-lysine adduct formation in the reaction between oxidized LA and lysine in conditions (a), (b) and (c) of Figure 4. The curves were based on the spectral changes monitored at $430 \mathrm{~nm}$, during $48 \mathrm{~h}$ after lysine addition. It can be observed that the formation of the oxLA-Lys adduct follows a sigmoid pattern with an apparent induction or "lag" phase, which is evident in curves (a) and (b). In curve (c) the reaction is still in an apparent lag phase until $48 \mathrm{~h}$ of monitoring, although a small rate of fluorophore formation can be detected since the beginning of the reaction.

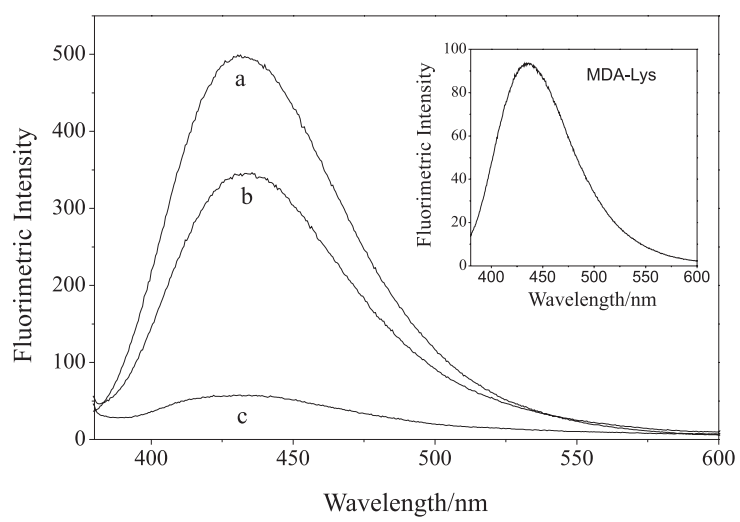

Figure 4. Emission spectra obtained after linoleic acid (LA) oxidation (final concentration $\left.1.2 \mathrm{mmol} \mathrm{L}^{-1}\right)$ catalyzed by $\mathrm{Fe}^{\mathrm{II}}$ ions $\left(\mathrm{FeSO}_{4}\right.$, final concentration $\left.5.0 \mathrm{mmol} \mathrm{L}^{-1}\right)$ for $2 \mathrm{~h}$, followed by incubation of the solution with lysine (Lys) (final concentration $1.0 \mathrm{mmol} \mathrm{L}^{-1}$ ) for $48 \mathrm{~h}$ at $37^{\circ} \mathrm{C}$ in the absence (a) and presence of GSNO $5.0 \mathrm{mmol} \mathrm{L}^{-1}$ (b) and $500.0 \mathrm{mmol} \mathrm{L}^{-1}$ (c). Excitation/emission wavelengths $360 / 430 \mathrm{~nm}$. Inset: Emission spectra of MDA incubated with Lys in equimolar concentrations of $0.25 \mathrm{~mol} \mathrm{~L}^{-1}$, used as a control.

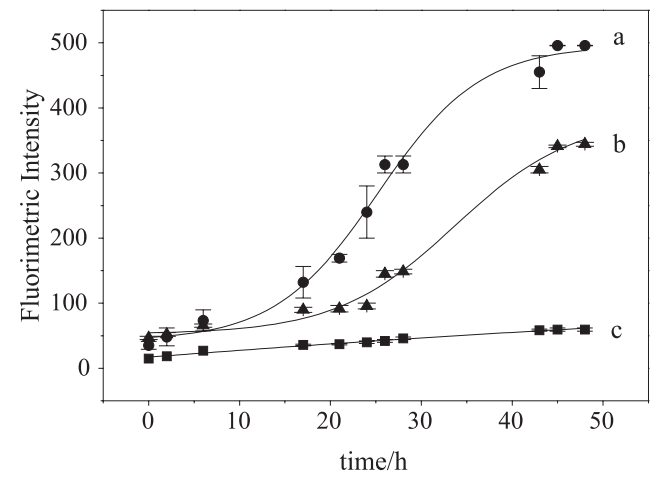

Figure 5. Kinetic curves of fluorescent oxidized LA-Lys adduct formation during the reaction between oxidized LA and Lys in the conditions (a), (b) and (c) of Figure 4, based on the spectral changes monitored at $430 \mathrm{~nm}$ during 48 h, after Lys addition. 


\section{Detection of LA peroxidation by infrared spectroscopy}

Figure 6 shows the spectral change in the normal infrared region, obtained after 2 and $4 \mathrm{~h}$ of heating of pure LA at $80{ }^{\circ} \mathrm{C}$ under $\mathrm{O}_{2}$ atmosphere. The new absorption band with maximum at $c a .1180 \mathrm{~cm}^{-1}$ can be assigned to the $\mathrm{C}-\mathrm{O}-\mathrm{O}$ vibration of hydroperoxides $(\mathrm{LOOH}){ }^{45}$

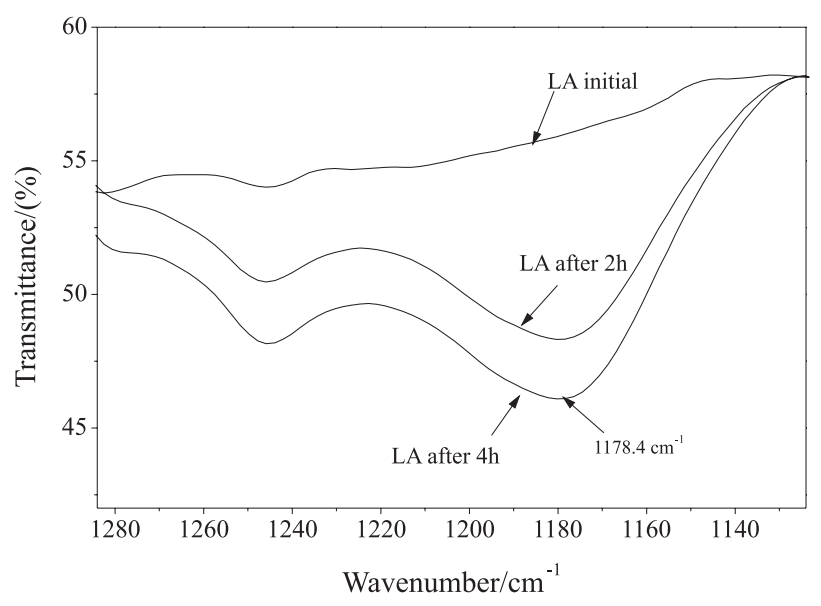

Figure 6. Infrared spectral changes associated with the formation of hydroperoxides in the oxidation of linoleic acid at $80{ }^{\circ} \mathrm{C}$ under $\mathrm{O}_{2}$ atmosphere for 2 and $4 \mathrm{~h}$.

\section{Detection of ${ }^{*} \mathrm{NO}$ released from nitrogen-containing products of oxidized LA}

Figure 7 shows the peaks of light emission obtained in the chemiluminescence reaction of free ${ }^{\circ} \mathrm{NO}$, released from nitrogen-containing products of oxLA, formed in the reaction between oxLA and GSNO. The two peaks shown were obtained after reduction of nitrogen-containing products of oxLA by ascorbate, according to the procedures described above. Peak (a) was obtained in the reduction of a sample of LA-SDS dispersion oxidized in the presence of $\mathrm{Cu}^{\mathrm{II}}$ ions and GSNO. The same result was observed when SNAC or CySNO were used in the place of GSNO (data not shown). Peak (b) was obtained in the reduction of a sample of LA-SDS dispersion incubated with GSNO, where pure LA had been previously oxidized by heating under $\mathrm{O}_{2}$ at $80^{\circ} \mathrm{C}$. The detection of free ${ }^{\circ} \mathrm{NO}$ in these cases shows that nitrogen-containing products of oxLA are formed either when LA is oxidized in aqueous dispersion in the presence of GSNO or when a dispersion of oxLASDS is subsequently incubated with GSNO. Control curves are for the measurements of samples of water incubated with GSNO without LA-SDS and $\mathrm{Cu}^{\mathrm{II}}$ (control 1), and of water incubated with $\mathrm{GSNO}$ and $\mathrm{Cu}^{\mathrm{II}}$ without LA-SDS (control 2), which show that GSNO was completely eliminated through decomposition by $\mathrm{Hg}^{\mathrm{II}}$ ions, followed by $\mathrm{NO}_{2}^{-}$trapping by sulfanilamide, before injection in the ascorbic acid soluti

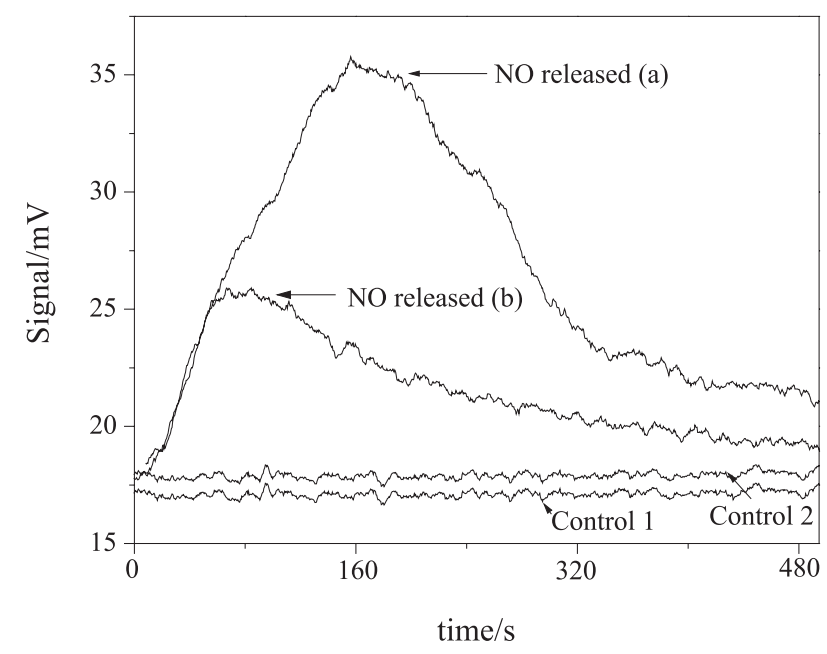

Figure 7. Light emission peaks obtained in the chemiluminescence reaction of ozone with free $\mathrm{NO}$, released in the reduction of nitrogencontaining products of oxidized linoleic acid (oxLA) formed in the peroxidation reaction of LA in the presence of GSNO $\left(900 \mu \mathrm{mol} \mathrm{L} \mathrm{L}^{-1}\right)$. For details see experimental part. Peak (a) was obtained for the product formed after the incubation of $\mathrm{LA}$ with $\mathrm{Cu}^{\mathrm{II}}$ ions $\left(900 \mu \mathrm{mol} \mathrm{L}^{-1}\right)$ in the presence of GSNO. Peak (b) was obtained for the product formed after the incubation of LA previously oxidized by heating under $\mathrm{O}_{2}$ with GSNO. Control curves are for the measurements of samples of water incubated with GSNO without LA-SDS and $\mathrm{Cu}^{\mathrm{II}}$ (control 1), and of water incubated with GSNO and $\mathrm{Cu}^{\mathrm{II}}$ without LA-SDS (control 2).

\section{Reaction between RSNOs and tert-butyl hydroperoxide}

Figure 8 shows the kinetic curves corresponding to the spectral changes due the disappearance of the RSNOs, CySNO, SNAC and GSNO, during their reaction with tertbutyl hydroperoxide $\left({ }^{t} \mathrm{BOOH}\right)$ with formation of tert-butyl peroxynitrites ('BOONOs). Control curves correspond to the monitoring of RSNOs solutions at the same temperature and $\mathrm{pH}$ conditions, but in the absence of ${ }^{t} \mathrm{BOOH}$. It can be seen that the RSNOs solutions are quite stable in the absence of $\mathrm{tBOOH}$ and that their thermal decompositions are negligible in this time range. On the other hand, the presence of ${ }^{t} \mathrm{BOOH}$ leads to the fast disappearance of the absorption bands of the three RSNOs, indicating that they react with ${ }^{t} \mathrm{BOOH}$. The rates of reaction of SNAC and GSNO are very similar and follow pseudo-first order kinetics. However, CySNO shows a different kinetic pattern, with an apparent bimodal behaviour. In this case, the rate of reaction is lower and approximately constant up to $c a .3 \mathrm{~min}$ and increases after this time, becoming similar to the rates observed in the last $4 \mathrm{~min}$ for SNAC and GSNO.

In the lipid pool of plasma and cells, polyunsaturated fatty acids (PUFAs) have higher propensity to oxidation due to the fact that bis-allylic methylene hydrogens are more 


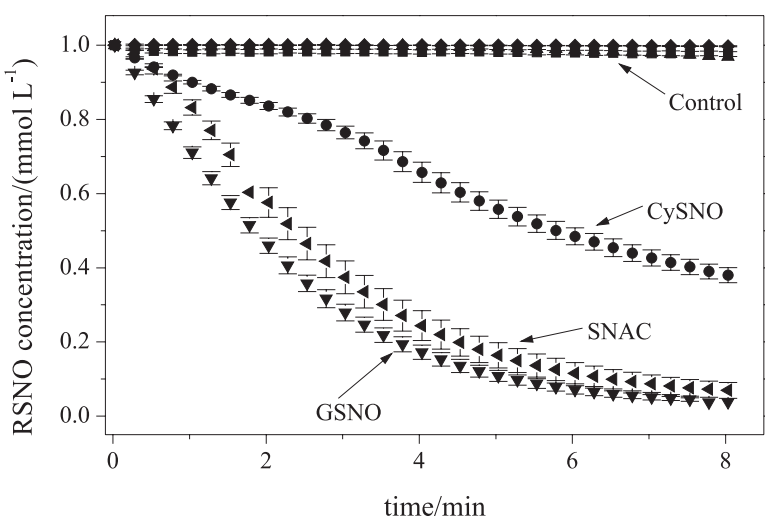

Figure 8. Kinetic curves corresponding to the spectral changes of CySNO, SNAC and GSNO (initial concentration $1.0 \mathrm{mmolL}^{-1}$ ) solutions in the presence and absence of ${ }^{t} \mathrm{BOOH}$ (final concentration $25 \mathrm{mmol} \mathrm{L}^{-1}$ ), monitored at $336 \mathrm{~nm}$ for $8 \mathrm{~min}$, at $37^{\circ} \mathrm{C}$. Control curves correspond to the thermal decomposition of RSNOs solutions in the same temperature and $\mathrm{pH}$ conditions but in the absence of $\mathrm{tBOOH}$.

susceptible to hydrogen abstraction by oxidizing radicals than the methylene hydrogens from fully saturated lipids. ${ }^{44}$ After such initiation process, the rapid reaction between the formed carbon-centered radical and dioxygen $\left(\mathrm{O}_{2}\right)$ forms a lipid peroxyl radical (LOO'). Propagation occurs via the reaction between $\mathrm{LOO}^{\circ}$ and intact fatty acid $(\mathrm{LH})$ molecules forming lipid hydroperoxides (LOOH), which leads to the formation of more $\mathrm{LOO}^{*}$ species through the decomposition of $\mathrm{LOOH}$ catalyzed by $\mathrm{Cu}^{\mathrm{II}}$ or $\mathrm{Fe}^{\mathrm{III}}$ ions either free or in the form of heme proteins. ${ }^{46-48}$ In addition, $\mathrm{LOOH}$ can lead to the formation of alkoxyl radicals mediated by $\mathrm{Fe}^{\mathrm{II}}$. These processes are represented in Scheme 1.

Linoleic acid (LA), one of the components of LDL particles, is a major unsatured fatty acid in the american diet and is considered to be atherogenic because of its pro-oxidative and pro-inflammatory response through the activation of endothelial cells. ${ }^{49,50}$ An increase in LA levels has been reported in the phospholipid fractions of human coronary arteries in cases of sudden cardiac death due to ischemic heart disease. ${ }^{51}$ Additionally, concentrations of LA in adipose tissue were positively correlated with the degree of coronary disease. ${ }^{52}$ Linoleic acid has a double bond configuration with bis-allylic methylene hydrogens (Scheme 1). Due to this characteristic, and due to the reasons mentioned above, LA is an appropriate model compound for LPO studies. The kinetic monitoring of conjugated double bond formation in LA-SDS comicelles catalyzed by SLO (Figure 2) shows that LA is effectively oxidized in aqueous dispersion by dissolved $\mathrm{O}_{2}$. It must be considered that, in this particular condition, SLO is also an appropriate catalyzer as a member of a well known group of enzymes able to induce enzymatic peroxidation of polyunsaturated fatty acids in biological membranes and lipoproteins. ${ }^{53,54}$ In general, such enzymes contain an essential iron atom, which is present as $\mathrm{Fe}^{\mathrm{II}}$ in the inactive enzyme form; enzymatic activation occurs through hydroperoxide-driven oxidation of $\mathrm{Fe}^{\mathrm{II}}$ to $\mathrm{Fe}^{\mathrm{III}}$.

Although the kinetics of lipoperoxidation induced by $\mathrm{SLO}, \mathrm{Cu}^{\mathrm{II}}$ and $\mathrm{Fe}^{\mathrm{II}}$ ions may be different, the formation of alkoxyl and peroxyl radicals is a common result in all cases, since hydrogen abstraction by any initiator in the presence of $\mathrm{O}_{2}$ will lead to the formation of these propagating species. The results of all experiments herein presented are in accordance with the inactivation of alkoxyl and peroxyl species by the RSNOs. The expected products in all cases are LOONO and LONO species. In fact, nitrated lipid formation have been shown to occur in vivo as potential "footprint" of the critical role that $\mathrm{NO}$ and/or NO-derived reactive species play during lipid oxidation processes. ${ }^{8}$ The RSNOs used here cannot be considered classical antioxidants like $\alpha$-tocopherol $(\alpha-\mathrm{TOH})$ or ascorbic acid. Although $\alpha-\mathrm{TOH}$ reacts with LOO forming a tocopheroxyl radical $\left(\alpha-\mathrm{TO}^{*}\right)$ which can scavenge another LOO' species, allowing two LOO' radicals to be scavenged by one $\alpha-\mathrm{TOH}$ molecule, the primary product of this reaction is $\mathrm{LOOH}$ and its accumulation may expose lipids to subsequent oxidation mediated by metal ions. ${ }^{48} \mathrm{~A}$ similar process can be described for other classical antioxidants found in cells, like ascorbic acid and glutathione (GSH).

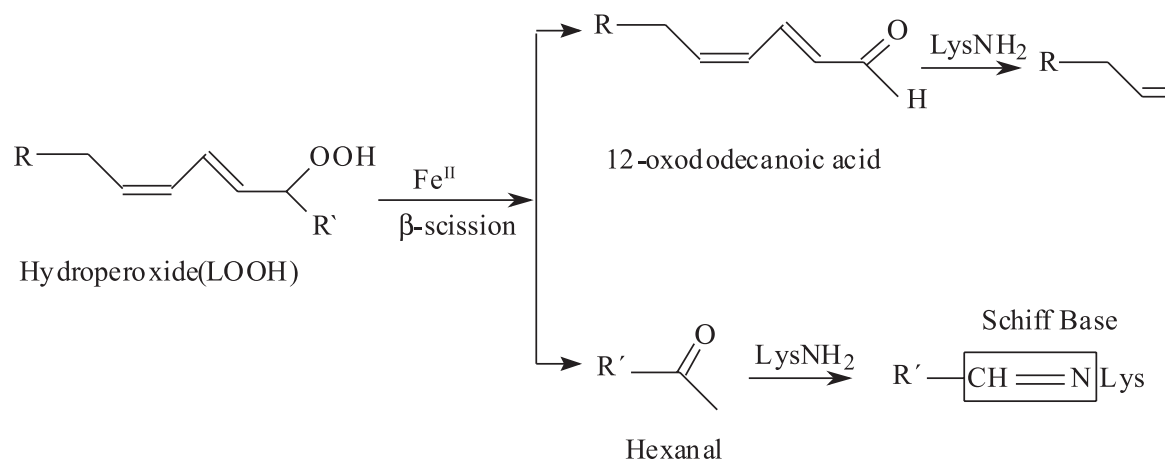

Scheme 1. Formation of lipid fluorescent oxidized LA-lysine adducts. 
Both are highly susceptible to hydrogen abstraction, generating ascorbyl and thyil radicals and leading to $\mathrm{LOOH}$ formation in their primary reactions. In the case of GSH, the fate of the glutathionyl radical (GS*) formed is dimerization, forming oxidized glutathione (GS-SG), the ration GSH/GS-SG being a well-known marker of oxidative stress. ${ }^{55}$ The protective actions of RSNOs are primarily linked to the well-known antioxidant action of ${ }^{\circ} \mathrm{NO}$ as a radical-chain terminator, which arises from the fact that ${ }^{\mathrm{NO}}$ is itself a free radical. Like its reaction with superoxide $\left(\mathrm{O}_{2}^{--}\right)$generating peroxynitrite $\left(\mathrm{ONOO}^{-}\right.$, $\left.\mathrm{k}=6.7 \times 10^{9} \mathrm{~L} \mathrm{~mol}^{-1} \mathrm{~s}^{-1}\right)^{56}$ free ${ }^{\circ} \mathrm{NO}$ may react extremely fast with LOO $\left(\mathrm{k}=2 \times 10^{9} \mathrm{~L} \mathrm{~mol}^{-1} \mathrm{~s}^{-1}\right)^{48}$ removing this chain carrying radical from the reaction scene. Although formation of $\mathrm{ONOO}^{-}$is usually associated with a prooxidant response reflected also in the nitration of tyrosine residues, ${ }^{48,57}$ the deleterious actions of $\mathrm{ONOO}^{-}$have been shown to depend strongly on the balance between ${ }^{\mathrm{NO}}$ and $\mathrm{O}_{2}^{-} \cdot{ }^{-48}$ More generally, the balance between oxidant species and ${ }^{\circ} \mathrm{NO}$ seems to be fundamental in allowing a protective action of ${ }^{\mathrm{NO}}$ against LPO. Hummel et al. ${ }^{20}$ for example, have shown that quite low levels of ${ }^{\circ} \mathrm{NO}\left(c a .50 \mathrm{nmol} \mathrm{L}^{-1}\right)$ are enough to suppress $\mathrm{Fe}^{\mathrm{II}}-\mathrm{O}_{2}$ lipid oxidation in vitro in cell models.

Although aqueous RSNOs solutions may spontaneous release free ${ }^{\mathrm{NO}}$ in vitro through the homolytic cleavage of the $\mathrm{S}-\mathrm{N}$ bond, the chemical stability of RSNOs solutions at low concentrations is high enough to allow these compounds to react directly with other substrates in a bimolecular mechanism. The decomposition of RSNOs with NO release may occur in several hours and days, depending on the experimental condition. ${ }^{19}$ In the present work, as shown in Figure 2, the kinetic curves of LA peroxidation were monitored for only $80 \mathrm{~s}$. In this time frame RSNOs are stable and the inhibition of lipid peroxidation can be assigned to the primary reactions between intact RSNOs molecules and oxyl/peroxyl species.

In the case of LA peroxidation, the primary reaction of RSNOs with LO` or LOO` species will lead to the formation of LOONO or LONO species and not to $\mathrm{LOOH}$ or LOH species, as in the case of hydrogen abstraction from classical antioxidants.

As a complementary analysis of the protective action of RSNOs in LPO, one may also consider that linoleate hydroperoxide $(\mathrm{LOOH})$ formed as a primary oxidation product of LA is expected to undergo $\beta$-scission generating free aldehydes. It is generally assumed that adducts formed in the conjugation of free aldehydes generated during peroxidation of PUFAs with amino groups on LDL particles are proteins with Schiff bases (containing the $-\mathrm{C}=\mathrm{N}$ - group). Formation of such adducts is central in the atherosclerotic process once it neutralizes the cluster of positive charges on the surface of LDL particles, conferring to them a higher anionic electrophoretic mobility and a reduced recognition by the LDL receptor on fibroblasts, while increasing their recognition by macrophages ${ }^{60}$ As Schiff bases have fluorescence properties, ${ }^{61,62}$ it was assumed in this work that such adducts could be used to characterize the formation of aldehydes from hydroperoxides in the peroxidation of LA. It was found here that the fluorescence emission spectra obtained after LA oxidation catalyzed by $\mathrm{Fe}^{\mathrm{II}}$ ions followed by incubation of the solution with Lys, has exactly the same shape and position of the spectrum obtained in the incubation of MDA with Lys (Figure 4). This result shows that products of LA peroxidation are also reactive toward lysine, forming the same fluorescent Schiff base adduct formed in oxidized LDL (like the MDAlysine adduct). The fluorescent adduct identified in this work was assigned to the reaction between the aldehydes formed from the reduction and b-scission of $\mathrm{LOOH}$, with lysine (Scheme 2). More specifically, the reaction involves the nucleophilic addition between the amino group of lysine and the carbonyl group of the aldehydes, forming hemiaminals, followed by dehydration to generate stable imines. In Scheme 2, these reactions are represented for the two possible aldehydic fragments of $\mathrm{LOOH} b$-scission: 12-oxododecanoic acid and hexanal. Of course, in different oxidative situations several other aldehydic products may form after LA peroxidation, which may also generate fluorescent adducts with lysine. In addition to the aldehydetype lysine adducts, amide-type-lysine adducts have also been described by Kawai and co-workers ${ }^{63,64}$ as a new class of protein adducts derived from lipid peroxidation.

The dose-dependent reduction in the amounts of aldehyde-type lysine adducts formed in the presence of GSNO $5.0 \mu \mathrm{mol} \mathrm{L} \mathrm{L}^{-1}$ and $500.0 \mu \mathrm{mol} \mathrm{L}{ }^{-1}$ in Figure 4, compared to the peroxidation reaction performed in the absence of GSNO, reflect the protective effect of GSNO in this particular peroxidation condition. This protective action is also reflected in the reduction of the rates and increase in the apparent lag phase of the aldehyde-type lysine adducts formation (Figure 5).

The formation of nitrogen-containing products of oxLA, induced by $\mathrm{Cu}^{\mathrm{II}}$ ions and heat, during the peroxidation of LA in the presence of RSNOs was demonstrated in the present work by reducing these products to free ${ }^{\mathrm{NO}}$ and hydroperoxides with ascorbic acid, according to procedures already described in other works. ${ }^{14}$ The reaction involved can be written as:

$$
\begin{aligned}
2 \mathrm{LOONO} / \mathrm{LONO}+\mathrm{AscH}^{-}+\mathrm{H}^{+} \rightarrow \\
2 \mathrm{LOOH} / \mathrm{LOH}+\mathrm{DHA}+2 \cdot \mathrm{NO}
\end{aligned}
$$




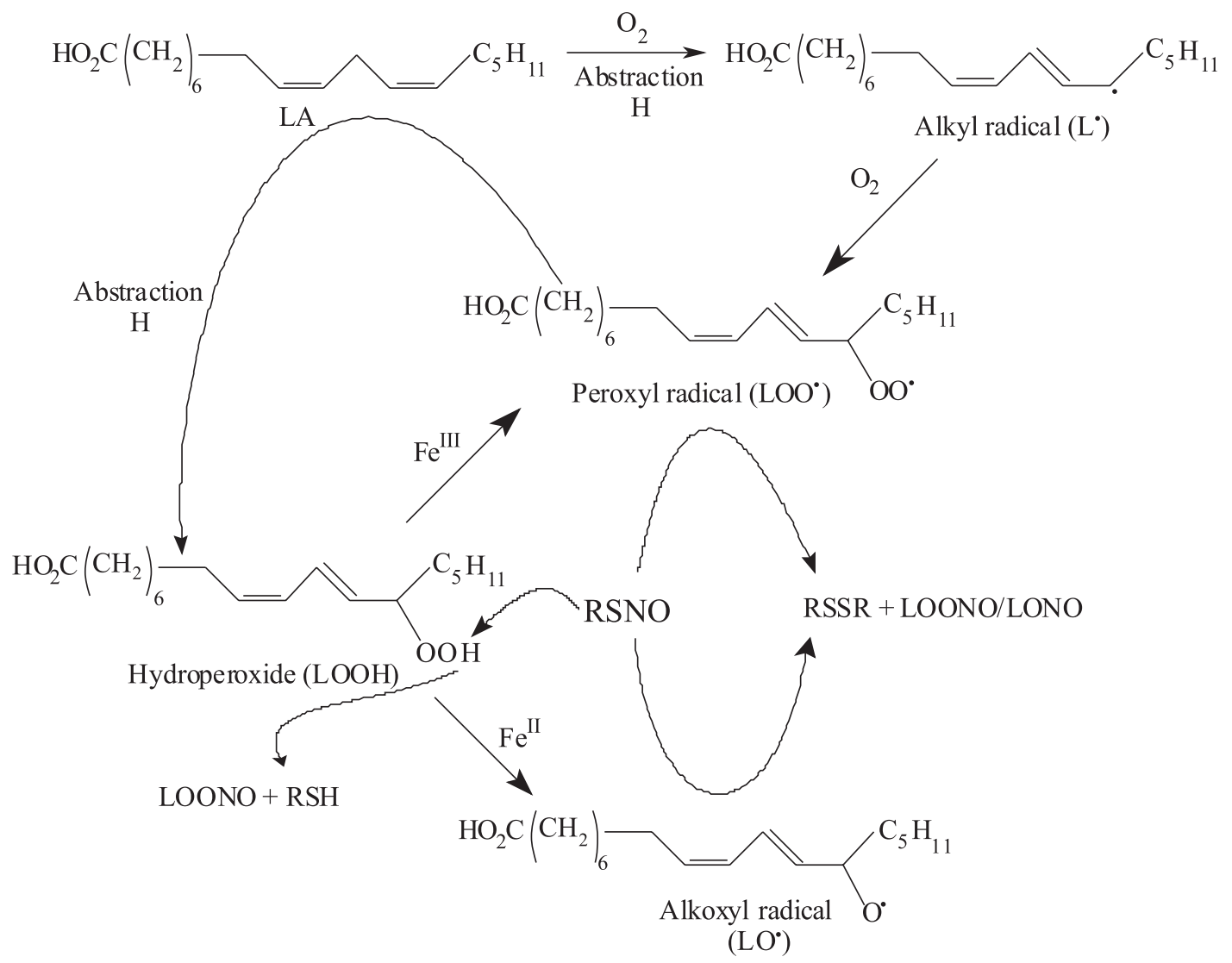

Scheme 2. Key sites of primary S-nitrosothiol action on pathways of linoleic acid peroxidation.

where $\mathrm{AscH}^{-}$is the ascorbate anion and DHA is dehydroascorbic acid formed in the oxidation (hydrogen abstraction) of $\mathrm{AscH}^{-}$. Free ${ }^{\mathrm{NO}} \mathrm{N}$ released in this reaction was unequivocally detected by chemiluminescence, after its removal from the solution by bubbling with $\mathrm{N}_{2}$ and its reaction with ozone $\left(\mathrm{O}_{3}\right)$. It must be emphasized here that to avoid any possible interference of ${ }^{\circ} \mathrm{NO}$ released from excess GSNO, instead of "NO released from nitrated LA, excess GSNO (which did not reacted with LOO') was completely eliminated from the solution by addition of $\mathrm{Hg}^{\mathrm{II}}$ ions and sulfanilamide. It is know that ${ }^{\circ} \mathrm{NO}$ is quantitatively liberated from GSNO' by mercuric catalysis, and it is rapidly and quantitatively converted to its stable solution end-product, nitrite $\left(\mathrm{NO}_{2}^{-}\right)$in aerated medium. By adding sulfanilamide to the solution, $\mathrm{NO}_{2}^{-}$formed is completely removed, and therefore the ${ }^{\circ} \mathrm{NO}$ signal detected in this analysis can be attributed solely to $\mathrm{NO}$ released from nitrogen-containing products of oxLA. This conclusion is supported by the control experiments, which confirmed that GSNO is completely eliminated by the mercuric catalysis/ sulfanilamide procedure. In addition, it was observed that RSNOs react with LA previously oxidized through heating, once incubation of oxLA-SDC comicelles with GSNOs, led also to the formation of nitrogen-containing products of oxLA, detected by their reduction to ${ }^{\circ} \mathrm{NO}$ with ascorbate. This result points to the ability of RSNOs to inactivate preformed LA hydroperoxides ( $\mathrm{LOOH})$. In this case, the bimolecular reaction is expected to proceed via a transnitrosation mechanism and can be written as:

$$
\mathrm{LOOH}+\mathrm{RSNO} \rightarrow \mathrm{LOONO}+\mathrm{RSH}
$$

It must be noted that the formation of $\mathrm{LOOH}$ in the LA oxidized by heating under $\mathrm{O}_{2}$ was proven by observing the appearance of an IR absorption band with maximum around $1180 \mathrm{~cm}^{-1}$, assigned to the $\mathrm{C}-\mathrm{O}-\mathrm{O}$ vibration of hydroperoxides $(\mathrm{LOOH}){ }^{45}$ The reactivity of RSNOs against tert-butyl hydroperoxide $\left({ }^{t} \mathrm{BOOH}\right)$ is an additional evidence for reaction 2. Although the different kinetic behavior of CysNO compared to SNAC and GSNO in Figure 8 is not reflected in the initial rates of LA peroxidation in Figure 3, it must be noted that reaction rates in Figure 3 were calculated over the first $20 \mathrm{~s}$ of reaction, while differences in the kinetic behavior among the three RSNOs in Figure 8 begin to appear after $60 \mathrm{~s}$. In addition, reaction rates in Figure 3 reflect not only the inactivation of $\mathrm{LOOH}$ by RSNOs but mainly of $\mathrm{LO}^{\star}$ and $\mathrm{LOO}^{*}$ species. Therefore, the evidences of the ability of primary RSNOs to block the propagation of 
lipid peroxidation reaction not only by inactivating $\mathrm{LO}^{\circ}$ or $\mathrm{LOO}^{*}$ radicals, but also by inactivating preformed $\mathrm{LOOH}$, reinforces the potential role of endogenous RSNOs as modulators of peroxidation reactions in vivo. The relevance of this evidence can be better appreciated by considering that the reduction of $\mathrm{LOOH}$ to $\mathrm{LO}^{*}$ radical by metal ions as $\mathrm{Fe}^{\mathrm{II}}$ or $\mathrm{Cu}^{\mathrm{II}}$ represents an important via for the propagation of radical reactions in the lipid peroxidation process. Although $\mathrm{SLO}, \mathrm{Fe}^{\mathrm{II}}$ and $\mathrm{Cu}^{\mathrm{II}}$ have chemical peculiarities, it might be consider that the three compounds lead to the formation of nitrogen containing products of oxLA,${ }^{8}$ which can release NO upon reduction with ascorbic acid. For example, it has been reported that lipid peroxidation of LA by lipoxygenase yielded nitrogen-containing lipid derivatives. ${ }^{8}$

Thus, if the role of endogenous ${ }^{\circ} \mathrm{NO}$ as an antioxidant species is linked in vivo to its presence in primary RSNOs, this role must be extended beyond its classical radical chain termination action, to encompass the inactivation of deleterious hydroperoxides also present in the cellular milieu. These multiple protective actions of RSNOs are summarized in Scheme 1 for the case of LA peroxidation and can be generalized for other lipids. These results raise the possibility that primary RSNOs are involved in the formation of nitrogen-containing lipids (and perhaps of nitroalkanes), which all may be natural membrane components and may have biological activities intimately linked with the biological activities of RSNOs.

\section{Acknowledgments}

F. I. S. held a studentship from CNPq, project 140702/2003-2. G. F. P. S. holds a studentship from FAPESP, project 07/55877-3. We thank FAPESP and CNPq for financial support.

\section{References}

1. Whitlock, D. R.; Nitric Oxide-Biol. Chem. 2006, 14, 68.

2. Kunsch, C.; Medford R. M.; Circ. Res. 1999, 85, 753.

3. de Oliveira, C. P. M. S.; Simplicio, F. I.;. de Lima, V. M. R.; Yuahasi, K.; Lopasso, F. P.; Alves, V. A. F.; Abdalla, D. S. P.; Carrilho, F. J.; Laurindo, F. R. M.; de Oliveira, M. G.; World J. Gastroenterol. 2006, 12, 1905.

4. de Oliveira, C. P. M. S.; Stefano, J. T.; de Lima, V. M. R.; Simplicio, F. I.; de Mello, E. S.; de Sá, V. M.; Corrêa-Giannella, M. L.; Alves, V. A. F.; Laurindo, F. R. M.; de Oliveira, M. G.; Giannela-Neto, D.; Carrilho, F. J.; J. Hepatol. 2006, 15, 725.

5. de Oliveira, C. P. M. S.; de Lima, V. M. R.; Simplicio, F. I.; Soriano, F. G.; de Mello, E. S.; de Souza, H. P.; Alves, V. A.; Laurindo, F. R.; Carrilho, F. J.; de Oliveira, M. G.; J. Am. Coll. Nutr. 2008, 27, 299.
6. de Oliveira, C. P. M. S.; Alves, V. A. F.; de Lima, V. M. R.; Stefano, J. T.; Debbas, V.; de Sá, S. V.; Wakamatsu, A.; CorrêaGiannella, M. L.; de Mello, E. S.; Havaki, S.; Tiniakos, D. G.; Marinos, E.; de Oliveira, M. G.; Giannella-Neto, D.; Laurindo, F. R.; Caldwell, S.; Carrilho, F. J.; Biochem. Pharmacol. 2007, 74, 290.

7. Girotti, A. W.; J. Lipid Res. 1998, 39, 1529.

8. Rubbo, H.; O`Donnell, V.; Toxicology 2005, 208, 305.

9. Letters, J. M.; Witting, P. K.; Christison, J. K.; Eriksson, A. W.; Pettersson, K.; Stocker, R.; J. Lipid Res. 1999, 40, 1104.

10. McMackin, C. J.; Vita, J. A.; Methods Enzymol. 2005, 396, 541.

11. Walkowska, A.; Kompanowska-Jezierska, E.; Sadowski, J.; Kidney Int. 2004, 66, 705.

12. Napoli, C.; Ignarro, L. J.; Nitric Oxide 2001, 5, 88.

13. Cooke, J. P.; Atheroscler. Suppl. 2003, 4, 53.

14. Lima, E.S.; Bonini, M. G.; Augusto, O.; Barbeiro, H. V.; Souza, H. P.; Abdalla, D. S. P.; Free Radic. Biol. Med. 2005, 39, 532.

15. Schopfer, F. J.; Baker, P. R. S.; Giles, G.; Chumley, P.; Batthyany, C.; Crawford, J.; Patel, R. P.; Hogg, N.; Branchaud, B. P.; Lancaster, J. R.; Freeman, B. A.; J. Biol. Chem. 2005, $280,19289$.

16. Hogg, N.; Kalyanaraman, B.; Joseph, J.; Struck, A.; Parthasarathy, S.; FEBS Lett. 1993, 334, 170.

17. Yamanaka, N.; Oda, O.; Nagao, S.; FEBS Lett. 1996, 398, 53.

18. Rubbo, H.; Trostchansky, A.; Botti, H.; Batthyány, C.; Biol. Chem. 2002, 283, 547.

19. Kelley, E. E.; Wagner, B. A.; Buettner, G. R.; Burns, C. P.; Arch. Biochem. Biophys. 1999, 370, 97.

20. Hummel, S. G.; Fischer, A. J.; Martin, S. M.; Schafer, F. Q.; Buettner, G. R.; Free Radic. Biol. Med. 2006, 40, 501.

21. Lima, E. S.; Di Mascio, P.; Rubbo, H.; Abdalla, D. S. P.; Biochemistry 2002, 41, 10717.

22. Freeman, B. A.; Baker, P. R. S.; Schopfer, F. J.; Woodcock, S. R.; Napolitano, A.; d'Ischia, M.; J. Biol. Chem. 2008, 283, 15515.

23. Coler, B.; Bloodsworth, A.; Clark, S. R.; Lewis, M. J.; Cross, A. R.; Freeman, B. A.; O’Donnell, V. B.; Circ. Res. 2002, 91, 375.

24. Schopfer, F. J.; Lin, Y.; Baker, P. R. S.; Cui, T.; Garcia-Barrio, M.; Zhang, J.; Chen, K.; Chen, Y. E.; Freeman, B. A; Proc. Natl. Acad. Sci. U.S.A. 2005, 102, 2340.

25. Wright, M. M.; Schopfer, F. J.; Baker, P. R. S.; Vidyasagar, V.; Powell, P.; Chumley, P.; Iles, K. E.; Freeman, B. A.; Agarwal, A.; Proc. Natl. Acad. Sci. U.S.A. 2006, 103, 4299.

26. Cui, T.; Schopfer, F. J.; Zhang, J.; Chen, K.; Ichikawa, T.; Baker, P. R. S.; Batthyany, C.; Chacko, B. K.; Feng, X.; Patel, R. P.; Agarwal, A.; Freeman, B. A.; Chen, Y. E.; J. Biol. Chem. 2006, 281, 35686.

27. Villacorta, L.; Zhang, J.; Garcia-Barrio, M. T.; Chen, X.; Freeman, B. A.; Chen, Y. E.; Cui, T.; Am. J. Physiol. 2007, 293, H770.

28. Baker, P. R. S.; Lin, Y.; Schopfer, F. J.; Woodcock, S. R.; Groeger, A. L.; Batthyany, C.; Sweeney, S.; Long, M. H.; Iles, K. E.; Baker, L. M. S.; Branchaud, B. P.; Chen, Y. E.; Freeman, B. A.; J. Biol. Chem. 2005, 280, 42464. 
29. Adams, M. R.; McCredie, R.; Jessup, W.; Robinson, J.; Sullivan, D.; Celermajer, D. S.; Atherosclerosis 1997, 129, 261.

30. Gladwin, M. T.; Adv. Exp. Med. Biol. 2006, 588, 189.

31. Seabra, A. B.; Fitzpatrick, A.; Paul, J.; de Oliveira, M. G.; Weller, R.; Brit. J. Dermatol. 2004, 151, 977.

32. Pignatelli, P.; Di Santo, S.; Buchetti, B.; Sanguigni, V.; Brunelli, A.; Violi, F.; FASEB J. 2006, 20, 1082.

33. Marcondes, S.; Cardoso, M. H. M.; Morganti, R. P.; Thomazzi, S. M.; Lilla, S.; Murad, F.; De Nucci, G.; Antunes, E.; Proc. Natl. Acad. Sci. U. S. A. 2006, 103, 3434.

34. Chen, C.; Huang, B.; Han, P. W.; Duan, S. J.; Prog. Biochem. Biophys. 2006, 33, 609 .

35. Batthyany, C.; Schopfer, F. J.; Baker, P. R. S.; Duran, R.; Baker, L. M. S.; Huang, Y.; Cervenansky, C.; Branchaud, B. P.; Freeman, B. A.; J. Biol. Chem. 2006, 281, 20450.

36. Giustarini, D.; Milzani, A.; Colombo, R.; Dalle-Donne, I.; Rossi, R.; Clin. Chim. Acta 2003, 330, 85.

37. de Oliveira, M. G.; Shishido, S. M.; Seabra, A. B.; Morgon, N. H.; J. Phys. Chem. A 2002, 106, 8963.

38. Roy, B.; Dhardemare, A. D.; Fontecave, M.; J. Org. Chem. 1994, 59, 7019.

39. Bainbrigge, N.; Butler, A. R.; Gorbitz, C. H.; J. Chem. Soc., Perkin Trans. 2 1997, 351.

40. Stamler, J. S.; Singel, D. J.; Loscalzo, J.; Science 1992, 258, 1898.

41. Nicolescu,A. C.; Reynolds, J. N.; Barclay, L. R. C.; Thatcher, G. R. J.; Chem. Res. Toxicol. 2004, 17, 185.

42. Krieger, M.H.; Santos, K.F.R.; Shishido, S.M.; de Oliveira, M.G.; Franchini, K.G.; Spadari-Bratfish, R.C.; Wanschel, A. A. C. B.; Estrela, H.F.G.; Santos, L.; Laurindo, F. R. M.; Nitric Oxide 2006, 14, 12.

43. Hart, T. W.; Tetrahedron Lett. 1985, 26, 2013.

44. Hogg, N.; Kalyanaraman, B.; Biophys. Acta 1999, 1411, 378.

45. Silvertein, R. M.; Franciz, X.; Spectrometric Identification of Organic Compounds, John Wiley \& Sons Inc.: New York, 1998.

46. Ohyashiki, T.; Kadoya, A.; Kushida, K.; Chem. Pharm. Bull. 2002, 50, 203.

47. Pinchuk, I.; Lichtenberg, D.; Prog. Lipid Res. 2002, 41, 279.

48. Patel, R. P.; Moellering, D.; Murphy-Ullrich, J.; Jo, H.; Beckman, J. S.; Darley-Usmar, V. M.; Free Radical Biol. Med. 2000, 28, 1780 .
49. Hennig, B.; Lei, W.; Arzuaga, X.; Ghosh, D. D.; Saraswathi, V.; Toborek, M.; J. Nutr. Biochem. 2006, 17, 766.

50. Young, V. M.; Toborek, M.; Yang, F.; McClain, C. J.; Hennig, B.; Metabolism 1998, 47, 566.

51. Luostarinen, R.; Boberg, M.; Saldeen, T.; Atherosclerosis 1993, 99, 187.

52. Hodgson, J. M.; Wahlqvist, M. L.; Boxall, J. A.; Balazs, N. D.; Am. J. Clin. Nutr. 1993, 58, 228.

53. Lapenna, D.; Ciofani, G.; Pierdomenico, S. D.; Giamberardino, M. A.; Cuccurullo, F.; Free Radical Biol. Med. 2003, 35, 1203.

54. Brash, A. R.; J. Biol. Chem. 1999, 274, 23679.

55. Rahman, I.; Biswas, S. K.; Jimenez, L. A.; Torres, M.; Forman, H. J.; Antioxid. Redox Signal. 2005, 7, 42.

56. O’Donnell, V. B.; Eiserich, J. P.; Chumley, P. H.; Jablonsky, M. J.; Krishna, N. R.; Kirk, M.; Barnes, S.; Darley-Usmar, V. M.; Chem. Res. Toxicol. 1999, 12, 83.

57. O`Donnell, V. B.; Freeman, B. A.; Cir. Res. 2001, 88, 12.

58. Nakano, E.; Williamson, M. P.; Williams, N. H.; Powers, H. J.; Biochim. Biophys. Acta 2004, 1688, 33.

59. Zhang, Y. H.; Hogg, N.; Proc. Natl. Acad. Sci. U. S. A. 2004, 21,7891 .

60. Cominacini, L.; Garbin, U.; Davoli, A.; Micciolo, R.; Bosello, O.; Gaviraghi, G.; Scuro, L. A.; Pastorino, A. M.; J. Lipid Res. 1991, 32, 349.

61. Fruebis, J.; Parthasarathy, S.; Steinberg, D.; Proc. Natl. Acad. Sci. U. S. A. 1992, 89, 10588.

62. de Oliveira, F. G.; Rossi, C. L.; de Oliveira, M. G.; Saad, M. J. A.; Velloso, L. A.; Cardiovasc. Res. 2000, 47, 567.

63. Kawai, Y.; Kato, Y.; Fujii, H.; Makino, Y.; Mori, Y.; Naito, M.; Osawa, T.; J. Lipid Res. 2003, 44, 1124.

64. Kawai, Y.; Fujii, H.; Kato, Y.; Kodama, M.; Naito, M.; Uchida, K.; Osawa, T.; Biochem. Biophys. Res. Commun. 2004, 313, 271.

Submitted: November 16, 2009

Published online: June 23, 2010

FAPESP has sponsored the publication of this article. 